\title{
Incumbency Reconsidered: Prospects, Strategic Retirement, and Incumbent Quality in U.S. House Elections
}

\author{
Walter J. Stone University of California, Davis \\ Sarah A. Fulton Texas A\&M University \\ Cherie D. Maestas Florida State University \\ L. Sandy Maisel Colby College
}

\begin{abstract}
Fundamental questions about incumbent safety have been difficult to answer because of the absence of adequate measures of incumbent prospects and incumbent quality. If incumbents retire because they are vulnerable, high reelection rates do not necessarily mean that electoral accountability is absent. Moreover, if the electoral success of incumbents reflects their high quality, high reelection rates do not necessarily indicate pathology in the system. Using explicit measures of incumbent prospects and personal quality based on district informant ratings, we find evidence of strategic retirement by incumbents in the 1998 elections, when standard prospects measures show no evidence of strategic withdrawal by incumbents. We also find an impact of incumbent quality on vote share consistent with the idea that high quality incumbents are rewarded in the electoral process. Although many are skeptical about the implications of incumbent safety in House elections, our results suggest a more optimistic reconsideration of incumbent electoral security.
\end{abstract}

"In 2002 and 2004, only 98 percent of incumbents were re-elected. Appalled, incumbents are working to eliminate that awful 2 percent."

-George F. Will ${ }^{1}$

$\mathrm{R}$ ecent congressional elections have contributed to a prevailing cynicism about the amount and meaning of competition in U.S. House races. The 2002 and 2004 reelection rates cited by George Will are only slightly above average, which leads many observers to conclude that House elections are inert, featureless affairs dominated by incumbents who manipulate the district and the electorate to stifle competition. This sort of popular speculation is reinforced by an academic literature suggesting that incumbents employ perquisites of their office to enhance their own security by reducing competition and creating disadvantages for potential challengers (Cover and Brumberg 1982; Fiorina 1977; Mayhew 1974). Needless to say, such assessments do not lead to optimistic conclusions about representative democracy in American politics.
Assessing the normative implications of high reelection rates among U.S. House incumbents has proven remarkably difficult because studies that do not take adequate account of incumbent reelection prospects may fail to appreciate the implications of strategic retirement. Likewise, if incumbent Representatives are high in the qualities and skills that voters value, and if high quality challengers are reluctant to enter races against formidable incumbents, high incumbent reelection rates should result (Erikson 1971; Mondak 1995a, 1995b; Zaller 1998). Reconsidering the meaning of incumbency in House elections, in short, means allowing for the possibility that strategic retirement is an anticipation of electoral difficulty and that high-quality incumbents are rewarded at the polls.

While we do not pretend to have the final word on how to interpret incumbent reelection rates, we do introduce two new expert-based measures of incumbent attributes-incumbent prospects and incumbent personal quality-to help explain why

${ }^{1}$ George F. Will, “Election Breakwater?” Newsweek, February 27, 2006, p. 68.

The Journal of Politics, Vol. 72, No. 1, January 2010, Pp. 178-190

doi:10.1017/S0022381609990557

(C) Southern Political Science Association, 2010

ISSN 0022-3816 
incumbents enjoy sizeable electoral advantages. The strategy of using expert opinions to measure concepts that are poorly operationalized through other indicators is common in other fields and disciplines but it has not been utilized in the study of congressional elections. We demonstrate that such measures permit a more nuanced look at the sources of incumbency advantage. By incorporating our measure of incumbent prospects into empirical models, we show that incumbent retirement is dominated by strategic considerations and that the personal qualities and job performance that citizens value in elected officials affect incumbents' prospects and vote shares. As a result, we are relatively optimistic about incumbent reelection rates and the lack of competition in House elections.

\section{Incumbent Prospects, Strategic Retirement, and Incumbent Quality}

Strategic retirement occurs when incumbents anticipate electoral vulnerability and withdraw to avoid defeat. If incumbents run when their prospects are good and retire when they are poor, then the apparent electoral advantage the incumbent's party enjoys when incumbents run for reelection may reflect incumbents' ability to forecast their future electoral prospects. Since incumbent reelection rates are calculated on the basis of incumbents who run, the absence of an adequate measure of incumbent prospects could lead us to miss the implications of strategic withdrawal. In other words, if all incumbents were compelled to run, the rate of incumbent reelection would be lower than would occur if incumbents retire strategically. Moreover, strategic withdrawal based on anticipated reactions could enforce electoral accountability as surely as a negative election result.

Gelman and King raise the issue of strategic withdrawal and reentry in their classic article proposing an unbiased measure of the incumbency advantage (Gelman and King 1990, 1152): "If incumbents frequently decided not to run for reelection because they knew they would be likely to lose, [our] estimator would be inconsistent." They go on to argue that the primary reason incumbents would be vulnerable is if they are tainted by scandal. Citing a study of corruption (Peters and Welch 1980), they contend that strategic retirement is of limited concern because corruption charges are rare and do not appear to be strongly related to incumbents' decisions about running (Gelman and King 1990). However, missteps in office and character flaws are often seen by voters and prospective challengers as a signal about incumbent quality, which may have electoral consequences. It is reasonable to assume that incumbents also recognize those vulnerabilities and might retire as a result.

Gelman and King control for incumbent prospects by including $\mathrm{t}-1$ incumbent vote share; some studies add a measure of district partisanship (e.g, Brady, D'Onofrio, and Fiorina 2000; Theriault 1998). Nonetheless, the evidence on incumbent strategic retirement is mixed (Brace 1985; Hall and Houweling 1995; Moore and Hibbing 1998; Theriault 1998; Wolak 2007). Cox and Katz point out the mischief that results from inadequately accounting for incumbent prospects:

If we estimate the incumbency advantage simply by looking at the coefficient on an incumbency dummy variable in a single vote equation, a portion of the gap we find between the incumbent party's performance with and without its incumbent candidate will be artifactual. It will be generated by the fact that all politics is local and the local politicians know it a lot better than we do [based on measures like previous vote share], so that incumbents' entry and exit decisions reveal information about which way the electoral winds were blowing. ${ }^{2}(2002,144)$

Although incumbents' exit decisions may not be entirely strategic (Groseclose and Krehbiel 1994; Hall and Houweling 1995), we provide a direct test of the claim that they are driven by prospects. To our knowledge, ours is the first such test that goes beyond a reliance on standard indicators of previous vote share and district partisan makeup. Our analysis indicates strong evidence for strategic retirement among House incumbents, which suggests that prospects of reelection, above and beyond observable election outcomes, enforce electoral accountability.

Our second line of inquiry asks whether the high prospects of reelection and large vote shares enjoyed by incumbents result from characteristics of the incumbent we associate with quality leadership such as personal character and performance. To consider this question we must observe the impact of variation

\footnotetext{
${ }^{2}$ Concluding that adequate instruments to specify a simultaneousequations analysis of entry do not exist, Cox and Katz study districts where the incumbent's departure was unexpected (by death or defeat in a primary). In such cases, the apparent incumbency effect is lower, presumably because the effects of strategic departure by the incumbent are controlled.
} 
in quality among incumbents on electoral success. The most common approach is to treat incumbency as a dummy variable - the incumbent runs or the seat is open. This is consistent with the use of officeholding experience as a measure of challenger quality, but since all incumbents by definition have officeholding experience, it does not differentiate among them. We require a measure of the personal qualities, skills, and accomplishments that voters value for their own sake, as distinct from strategic qualities and skills such as name recognition and fundraising ability. Such strategic qualities may enhance reelection prospects, but would not alter a negative view of high incumbent reelection rates. If, in contrast, incumbents are rewarded for their competence and personal quality, their reelection reinforces, rather than undermines, core democratic values (Mondak 1995a).

In sum, our approach is to treat both the prospects and incumbent-quality questions as an omittedvariable problem because neither variable is adequately measured in studies of the incumbency effect in U.S. House elections. Absent an adequate measure of prospects, estimates of the incumbency effect are biased because of strategic entry and exit decisions; absent an incumbent-quality measure, attempts to assess the meaning of high incumbent reelection rates are impaired because they cannot adequately consider the possibility that the electoral process rewards highquality incumbents and punishes those of lesser quality. In light of the problems associated with these two omitted variables for our understanding of electoral competition in U.S. House elections, we propose a new strategy for measuring incumbent prospects and quality.

\section{A New Approach to Measuring Prospects and Quality}

One reason that prospects and quality are omitted from studies of congressional elections is the absence of valid and reliable measures. We make use of expert informants, a measurement strategy common in other fields and disciplines. Within political science, informants have been surveyed to measure agency placement on the left-right scale (Clinton and Lewis 2008) and to place political parties in western democracies on specific issues or the left-right scale (Benoit and Laver 2007; Castles and Mair 1984; Huber and Inglehart 1995; Ray 1999). In fields such as marketing and organizational behavior, the use of informants is common to measure characteristics of organizations that otherwise would be difficult or impossible to observe (Anderson 1985; Seidler 1974; Van Bruggen, Lilien, and Kacker 2002). To the best of our knowledge, we are the first to use informants in a congressional study, although Mondak (1995b) used descriptors culled from the Almanac of American Politics to rate incumbents' integrity and competence.

Our incumbent prospects and quality data were generated by the Candidate Emergence Study (CES) surveys of activists and potential candidates in a national random sample of 197 U.S. House districts. The activist survey was of Democratic and Republican national convention delegates and county chairs who were selected in equal numbers by party in each district. The potential-candidate survey was of state legislators whose districts overlapped substantially with the U.S. House districts in our sample, and of people in the district named by activists as individuals who would make strong House candidates if they were to run. ${ }^{3}$

We surveyed district activists in the summer of 1997 and the potential candidates three to four months before the filing deadlines in their states. Our goal was to measure incumbent prospects and quality on the premise that district activists and potential candidates understand the local conditions of their districts and have the information necessary to assess the performance and personal quality of the incumbent. We sought their perceptions before incumbent and challenger entry decisions were made so that our prospects measure would not be contaminated by events during the 1998 election cycle.

We treat both the activists and potential candidates as expert informants knowledgeable about the district and the incumbent. We combine the activist and potential-candidate samples in this study because we asked all of the relevant questions on both surveys, and doing so increases the number of informants per district. The median number of activists per district is twice the median number of potential candidates (eight vs. four); therefore including the potential candidates as informants increases the district-informant samples by $50 \%$.

We measure prospects by asking district experts to estimate the incumbent's chances of winning reelection if he or she runs in the next election and

\footnotetext{
${ }^{3} \mathrm{We}$ received usable responses from $32 \%$ of named potential candidates and state legislators and from $43 \%$ of activists.
} 
wins the primary. ${ }^{4}$ We do not have incumbents' perceptions of their own prospects, nor are the vast majority of actual challengers included in our sample of potential candidates in 1998. We assume that district informants' perceptions prior to the election season were shared by individual incumbents and potential candidates who were deciding whether to run. ${ }^{5}$ Our method takes advantage of the judgments of individuals in the district, each of whom has incomplete information. Aggregated assessments of individuals who make independent judgments about complex phenomena can be remarkably accurate (Surowiecki 2004). Of course, incumbents' and challengers' electoral prospects change as events leading up to the election unfold, but the point of measuring incumbent prospects before the electoral cycle begins is to capture the exogenous effects of prospects before they are influenced by challenger entry and incumbent exit decisions. ${ }^{6}$

\section{Exploring Incumbent Prospects}

Our use of district informants requires scrutiny of the validity and reliability of the approach and measures. The appendix analyzes the validity and reliability of informant-based indicators based on comparisons with criterion variables when available, and assessments of item and interrater reliabilities. In this section we

${ }^{4}$ Questions were scored on 7-point scales with responses ranging from "Extremely Unlikely" through "Tossup" to "Extremely Likely." We scored the items on pseudo-probability scales ranging in value from .01 to .99 , with "Tossup" coded .5. This scoring makes the data easier to understand and to manipulate, but we do not think of the results as probability scores. Rather, they are subjective measures of electoral prospects. We use the data to make comparative statements rather than as estimates of the probability of a particular event. The incumbent-prospects items included a question about the chances the incumbent would win the party's nomination if he or she ran, and the chances the incumbent would win the general election if he or she won the primary. The prospects measure employed in this paper is based on the general-election item.

${ }^{5} \mathrm{~A}$ major point of the CES was to identify and study the decisionmaking process of strong potential candidates who choose not to run, a key to understanding incumbent deterrence. Elsewhere (Stone, Maisel, and Maestas 2004), we provide an individual-level analysis of the effects of potential candidates' perceptions of incumbent prospects on their perceptions of their own chances and on the chances they would run in their district.

${ }^{6}$ Our approach contrasts with Abramowitz (1991) and Erikson and Palfrey (2000) who employ Congressional Quarterly ratings of competitiveness to measure incumbent prospects. While their measure is also based on elite perceptions, it is taken after incumbent- and challenger-entry decisions were made and is therefore endogenous to the phenomena of interest. explore the incumbent prospects measure by analyzing its relationship with election outcomes.

Figure 1 presents the bivariate relationship between the mean informant rating of incumbent prospects and the vote share the incumbent's party received in the fall election. For now, we exclude districts in which no challenger ran. It is clear from the figure that prospects are far from perfectly related to vote share. Indeed, only about $27 \%$ of the variance in vote share is accounted for by prospects $(r=.52)$. One explanation for the error is that we measure prospects well in advance of the election itself, and much can change between the point in the cycle when we tapped informant judgments and Election Day. Another is that prospects are not the same thing as vote share, and had we asked informants to forecast the incumbent's vote share, the fit would be better. Whatever one makes of the relationship, a comparison of the lowess and OLS fit curves indicates that the relationship between vote share and prospects is essentially linear. While this is not necessarily what we would expect a priori (Lee 2008), treating the relationship as nonlinear does not seem warranted nor does it alter or enhance any of the results reported in this paper.

The median value of incumbent prospects in our sample is .89. While we do not interpret this as a precise probability estimate that the average incumbent would get reelected if she/he ran in 1998, it is consistent with the expectation that incumbents typically had strong prospects. In keeping with the electoral security of incumbents in 1998, only $6.6 \%$ had their prospects rated lower than .70, with another

\section{Figure 1 Incumbent Party 1998 Vote Share by Incumbent Prospects}

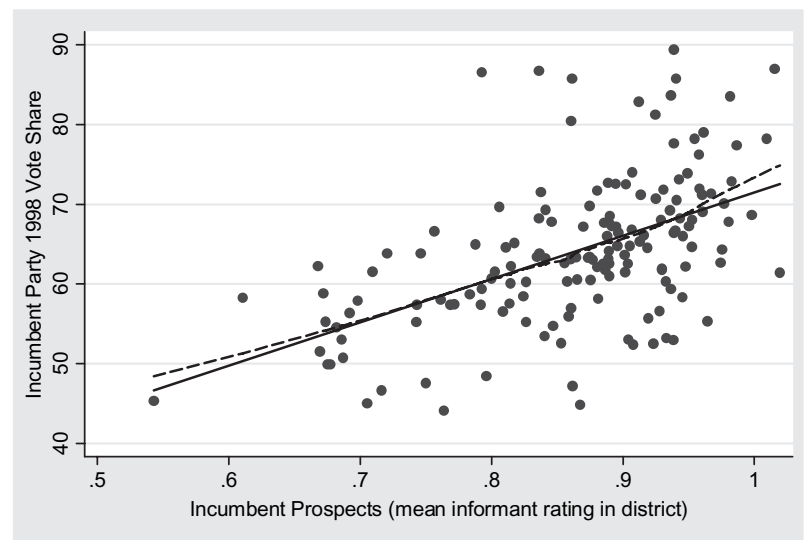

Note: Analysis limited to districts in which the incumbent faced a major-party challenger. The solid line is the OLS linear fit between the two variables; the dashed line is the lowess smoothed curve. 
$4.6 \%$ estimated by informants as having prospects between .70 and .75 . District informants understood that incumbents in 1998 were a safe bet for reelection.

Table 1 explores in greater detail the relationship between informants' perceptions of incumbent prospects and incumbent vote share in the 1998 elections. Equation (1) shows a strong bivariate relationship, such that over the range of observed variation in incumbent prospects in the sample (between .54 and 1.0) the difference between the incumbent judged most vulnerable and the safest incumbent is about 34 general-election percentage points. Equation (2) includes additional variables that should relate to the fall election results and that are typically used as measures of incumbent prospects: the incumbent's vote share in the previous election, the partisan makeup of the district, and the party of the incumbent. Not surprisingly, the effect of prospects drops when these indicators are included. However, even with these surrogates for prospects included, a strong and significant independent effect of prospects on incumbents' vote share remains. The expected difference between the most vulnerable and the most secure incumbents in our sample is approximately $13 \%$ in vote share, independent of how well the incumbent ran in 1996 and of the partisan makeup of the district. This is strong evidence that district informants had access to local information relevant to their incumbents' electoral prospects and that our measure provides substantial leverage beyond the standard indicators.

One possible concern is that the results in equation (2) may be produced by "easy" cases such as invulnerable incumbents who routinely dissuade a challenge. These cases might produce outliers that drive the effect of prospects, inflating our confidence in the measure. To address this and the related possibility that the results are produced by incumbents who are inordinately vulnerable, equation (3) includes dummy variables for districts in which no challenger ran against the incumbent in 1998 and the Congressional Quarterly key race dummy. This provides a stiff test for the prospects measure because both the willingness of challengers to run against an incumbent and the CQ indicator are endogenous to incumbent prospects, but over controlling in this way does not eliminate a strong and significant independent effect of prospects. ${ }^{7}$

\footnotetext{
${ }^{7}$ Of course, 1996 incumbent vote share and district partisanship also affect incumbent vote share independent of prospects. Some of these effects are undoubtedly due to measurement error in our prospects measure, but some also reflect the fact that incumbent vote share at $t-1$ and district partisanship are better criterion variables for incumbent vote share at $t$ than even an error-free incumbent-prospects measure. To be on the conservative side we include them as controls in subsequent analysis.
}

We conclude from Table 1 that our informant surveys add significantly to our ability to measure incumbent prospects for reelection, beyond the information contained in other generally available indicators.

\section{Incumbent Retirement and Challenger Entry}

We begin by examining the bivariate relationship between a grouped version of the prospects measure and various measures of candidate entry. As the results in Table 2 make clear, incumbent prospects relate in sensible ways to candidate-entry decisions by incumbents, challengers, and primary contestants. Incumbent retirement and the appearance of a serious-or any-challenger appears to be highly responsive to prospects. As incumbent prospects drop, the likelihood of a strong challenger jumps appreciably. ${ }^{8}$ The incidence of incumbents receiving primary challenges declined as their prospect ratings improved, as did contested primaries in the opposition party. Vulnerable incumbents should attract inparty challenges, especially in one-party districts, because winning the primary is the only avenue to taking the seat. Out-party primaries are also contested when incumbents are vulnerable because the value of the out party's nomination increases as the incumbent's chances of general-election victory decline. $^{9}$

Table 3 presents multivariate analyses of incumbents' decision to run and strong-challenger entry in 1998. The analysis of incumbents' decisions whether to retire or run for reelection is especially revealing because the model based on standard indicators of incumbent prospects fails to detect any evidence of

\footnotetext{
${ }^{8}$ Our measure of serious challengers includes all candidates with prior electoral experience and those serious amateurs who contributed more than $\$ 31,833$ of personal funds to their own campaign (Maestas and Rugeley 2008). Only 25\% of all nonincumbent candidates, experienced or not, contributed more than this amount during the 1994-2000 period (in constant 2000 dollars). Amateurs who commit substantial resources to their own campaigns raise funds and win votes at levels that rival that of many experienced office holders. Based on this measure, $60 \%$ of races in 1998 had a weak challenger or no challenger, $15 \%$ had a serious amateur challenger, and $25 \%$ had an experienced challenger. Our substantive conclusions do not differ when we use office-holding experience to measure challenger quality.

${ }^{9}$ Other indicators of "divisive primaries" are also associated with incumbent prospects in the same way, including the number of primary candidates who run and the share of the vote they receive. Lazarus (2005) provides an excellent critique of the literature on the "divisive primary effect" from the perspective of incumbent vulnerability and challenger entry.
} 
Table 1 Incumbent Prospects and Incumbent Vote Share (OLS)

\begin{tabular}{|c|c|c|c|c|c|c|}
\hline & \multicolumn{2}{|c|}{ (1) } & \multicolumn{2}{|c|}{ (2) } & \multicolumn{2}{|c|}{ (3) } \\
\hline & $\boldsymbol{b}$ & $S E$ & $\boldsymbol{b}$ & $S E$ & $\boldsymbol{b}$ & $S E$ \\
\hline Incumbent prospects, 1998 & $74.126^{\star *}$ & 12.506 & $27.924^{\star}$ & 11.773 & $25.472^{\star \star}$ & 7.565 \\
\hline Incumbent vote share, 1996 & & & $.500^{\star \star}$ & .089 & $.209^{* \star}$ & .058 \\
\hline District partisanship (favor incumbent) & & & $.343^{\star *}$ & .106 & $.327^{\star *}$ & .065 \\
\hline Democratic incumbent & & & $-4.156^{\star}$ & 1.956 & -1.307 & 1.212 \\
\hline CQ key race, 1998 & & & & & -3.252 & 1.849 \\
\hline No challenger, 1998 & & & & & $21.109^{\star \star}$ & 1.290 \\
\hline Constant & 5.888 & 11.056 & $-1,337$ & 9.409 & 14.825 & 6.488 \\
\hline Adjusted $R^{2}$ & \multicolumn{2}{|c|}{.168} & \multicolumn{2}{|c|}{.431} & \multicolumn{2}{|c|}{.786} \\
\hline$F$ & \multicolumn{2}{|c|}{$35.13^{\star \star}$} & \multicolumn{2}{|c|}{$32.97^{\star \star}$} & \multicolumn{2}{|c|}{$104.21^{\star *}$} \\
\hline$N$ & \multicolumn{2}{|c|}{170} & \multicolumn{2}{|c|}{170} & \multicolumn{2}{|c|}{170} \\
\hline
\end{tabular}

${ }^{* *} p<.01 ;{ }^{*} p<.05$; two-tailed tests.

Note: Analysis restricted to districts in which the same incumbent ran in 1996 and 1998.

strategic retirement in 1998. The model includes standard indicators of incumbent electoral vulnerability, including vote share in 1996 and partisan makeup of the district. However, none of these variables significantly relates to incumbent retirement/ entry. The only significant predictor in equation (1) is incumbent seniority, which is a measure of the incumbent's age or career stage rather than of electoral vulnerability. The absence of strategic retirement by incumbents may not be surprising since 1998 was an election without a national tide of the sort that might alert incumbents of their vulnerability.

In contrast, our informant-based measure of prospects performs quite well in predicting retirement (see equation 2). The coefficient is correctly signed and statistically significant. Moreover, analysis of predicted probabilities shows that the effect is substantively significant. As one would expect, when prospects are set to their mean value, along with all other variables in the model, the predicted probability of the incumbent running is .99 . This comports well with expectations since most incumbents choose to run for reelection rather than leave. However, when prospects are set at its lowest value in our sample (.54) and all other variables are at their mean or mode, the probability of the incumbent running is only .12. Indeed, it is not until prospects increase to about .66 that incumbents are more likely than not to run. Thus, including the prospects measure provides a clear indication that incumbents retired in response to diminished prospects for reelection, even in the absence of a national tide.

Equation 3 shows that serious challenger entry is responsive to the standard measures of incumbent prospects such as the incumbent's previous vote share, district party balance, and the party of the incumbent. However, equation (4) indicates that our measure of prospects also has a strong, independent effect on challenger entry. The effects of incumbent prospects on the decisions of incumbents and strong challengers can be seen in Figure 2. As incumbent prospects increase, the probability of a strong challenger emerging drops dramatically.

In short, prospects matter-a lot. Evidence from district informants supports the Cox and Katz (2002, 144) assertion that local politicians know their district (and their incumbent) far better than remote observers relying on surrogate measures like district partisanship and previous vote share. By including an explicit measure of prospects, we confirm that incumbents and strong challengers enter races they think they can win and opt out of races they expect to lose.

\section{The Effect of Incumbent Quality}

If prior elections select high-quality candidates who then become incumbents, high reelection rates should occur both because potential challengers would be deterred from challenging well-regarded incumbents, and because of voter satisfaction with their representative (Erikson 1971; Mondak, 1995a, 1995b; Zaller 1998). In other words, if the electoral process works as it should, poor-quality incumbents should be weeded out and high quality incumbents should be rewarded with reelection. If incumbents succeed because they are high quality, then the state of electoral competition in U.S. House elections may be less problematic than some conclude. To consider this question we must be able to 
TABLE 2 Incumbents' Prospects for Winning and Candidate Entry, 1998

\begin{tabular}{|c|c|c|c|c|c|}
\hline & \multicolumn{5}{|c|}{ Incumbent General Election Prospects } \\
\hline & $<.68$ & $.68-.749$ & $.75-.849$ & $.85-.949$ & $.95+$ \\
\hline Incumbent retired & $37.5 \%$ & $21.4 \%$ & $0 \%$ & $3.9 \%$ & $3.2 \%$ \\
\hline Experienced challenger ran & $62.5 \%$ & $42.9 \%$ & $36.6 \%$ & $19.4 \%$ & $12.9 \%$ \\
\hline Serious Challenger $\operatorname{ran}^{\mathrm{b}}$ & $100 \%$ & $71.4 \%$ & $48.8 \%$ & $36.6 \%$ & $12.9 \%$ \\
\hline No challenger ran & $0 \%$ & $7.1 \%$ & $19.5 \%$ & $24.3 \%$ & $29.0 \%$ \\
\hline In-party primary contested & $50.0 \%$ & $42.9 \%$ & $7.3 \%$ & $22.3 \%$ & $12.9 \%$ \\
\hline Out-party primary contested & $75.0 \%$ & $71.4 \%$ & $19.5 \%$ & $28.2 \%$ & $16.3 \%$ \\
\hline$N$ of districts & (8) & (14) & (41) & (103) & $(31)$ \\
\hline
\end{tabular}

${ }^{\mathrm{a}}$ Challenger had elective office-holding experience before running for House.

${ }^{\mathrm{b}}$ Challenger meets office-holding or top-quartile criteria.

observe how variation in incumbent quality affects electoral success.

Studies rarely distinguish among incumbents on the basis of quality. ${ }^{10}$ Instead, they treat the advantages associated with incumbency as hinging on an unspecified combination of skills, resources, and qualities with the analysis focusing on whether or not the incumbent runs, rather than the effect of variation in quality among incumbents. Our approach is to measure the personal qualities, skills, and performance of incumbents. If incumbents are rewarded for their personal quality, then their reelection reinforces, rather than undermines, core democratic values.

We asked informants to evaluate incumbents on items that most citizens would regard as important for the job of Representative, including personal integrity, ability to work with other leaders, grasp of the issues, ability to solve problems, ability to keep in touch with the district, and legislative accomplishment. Evidence on the reliability and validity of the personal quality measure is summarized in the appendix.

Incumbents' quality may help explain their safety by at least two mechanisms. The first is that lowquality incumbents may have reduced electoral prospects and either be deterred from running for reelection or they may attract a strong challenger. Second, incumbents of relatively high quality may be rewarded at the polls while incumbents of lesser

\footnotetext{
${ }^{10}$ A notable exception is Jeffery Mondak (1995b), who coded descriptions of incumbents in the Almanac of American Politics to measure incumbent quality, which he conceived as composed of integrity and competence. In addition, some have studied the effects of scandal, which does speak to one source of variation in incumbent quality (e.g., Jacobson and Dimock 1994).
}

quality are punished, over and above any effect of quality on prospects, challenger entry, or incumbent retirement (cf. Carson, Engstrom, and Roberts 2007; Cox and Katz 1996). Both mechanisms are linked to electoral sanctions: the first by the effect of quality on prospects, and the second by the reactions of voters on Election Day. If either or both mechanisms are at work, a quality effect will suggest that high reelection rates are due in part to the electoral process working as it should by rewarding high-quality incumbents and weeding out those of lesser quality.

Table 4 shows that incumbents judged high in their quality had more secure reelection prospects. The difference between the lowest and highest quality incumbents' prospects- 0.098 -is large enough to affect an incumbent's decision to run or retire. Likewise, a drop in incumbent prospects of .098 increases the chances of drawing a strong challenger by nearly .12. Based on the results in Table 3 (equation 4), the odds of drawing a challenger shift from 1 in $5(.21)$ to about 1 in 3 (.33). This effect, therefore, is consistent with the idea that the electoral process rewards higher quality incumbents indirectly though electoral prospects. Moreover, incumbent personal quality has an effect similar to other variables normally considered to be key determinants of prospects such as previous vote margin and district partisanship. A one standard deviation increase over the mean of the incumbent's previous vote margin (an increase of 12\%) boosts predicted prospects from .885 to .909 ; a one standard deviation increase in district partisanship (10\% increase toward the incumbent party) increases prospects from .885 to .906 ; and a one standard deviation increase in incumbent quality (an increase of .51 on the 7-point scale), leads to an increase in prospects from .885 to .904 . Thus, the magnitude of the response to personal quality is similar to that of 
Table 3 Candidate Entry in the 1998 Elections (Probit)

\begin{tabular}{|c|c|c|c|c|c|c|c|c|}
\hline & \multicolumn{4}{|c|}{ Incumbent Runs for Reelection } & \multicolumn{4}{|c|}{ Serious Challenger Enters } \\
\hline & \multicolumn{2}{|c|}{ (1) } & \multicolumn{2}{|c|}{$(2)$} & \multicolumn{2}{|c|}{ (3) } & \multicolumn{2}{|c|}{$(4)$} \\
\hline & $b$ & $S E$ & $\boldsymbol{b}$ & $S E$ & $b$ & $S E$ & $b$ & $S E$ \\
\hline $\begin{array}{l}\text { Incumbent vote } \\
\text { share, } 1996\end{array}$ & -0.006 & 0.034 & -0.052 & 0.040 & $-0.104^{\star \star}$ & 0.028 & $-0.087^{\star *}$ & 0.030 \\
\hline $\begin{array}{l}\text { District partisanship } \\
\quad \text { (favor } \\
\text { incumbent) }\end{array}$ & 0.012 & 0.024 & -0.011 & 0.029 & -0.026 & 0.019 & -0.023 & 0.019 \\
\hline $\begin{array}{l}\text { Democratic } \\
\text { incumbent }\end{array}$ & -0.239 & 0.424 & 0.455 & 0.590 & $0.694^{\star}$ & 0.266 & 0.540 & 0.276 \\
\hline $\begin{array}{l}\text { Incumbent } \\
\text { spending, } 1996 \\
\text { (logged) }\end{array}$ & 0.235 & 0.218 & 0.459 & 0.244 & -0.195 & 0.168 & -0.212 & 0.172 \\
\hline $\begin{array}{l}\text { Challenger } \\
\text { spending, } 1996 \\
\text { (logged) }\end{array}$ & -0.350 & 0.238 & $-0.668^{\star}$ & 0.328 & 0.027 & 0.116 & 0.072 & 0.119 \\
\hline $\begin{array}{l}\text { Serious challenger } \\
\quad \text { ran, } 1996\end{array}$ & 0.290 & 0.405 & 0.640 & 0.519 & 0.278 & 0.267 & 0.266 & 0.272 \\
\hline $\begin{array}{l}\text { Incumbent war } \\
\text { chest, } 1996 \\
\text { (logged) }\end{array}$ & -0.093 & 0.148 & -0.347 & 0.198 & 0.111 & 0.098 & 0.159 & 0.101 \\
\hline $\begin{array}{l}\text { Incumbent's } \\
\text { number of terms } \\
\text { served }\end{array}$ & $-0.109^{\star *}$ & 0.035 & $-0.142^{\star \star}$ & 0.045 & 0.038 & 0.028 & 0.033 & 0.029 \\
\hline $\begin{array}{l}\text { Incumbent's } \\
\text { prospects, } 1998\end{array}$ & - & & $9.935^{\star *}$ & 2.797 & - & & $-3.331^{\star}$ & 1.538 \\
\hline Constant & 4.168 & 5.776 & 3.350 & 7.155 & $7.919^{\star}$ & 3.544 & $8.883^{\star}$ & 3.614 \\
\hline Log Likelihood & \multicolumn{2}{|c|}{-34.754} & \multicolumn{2}{|c|}{-25.752} & \multicolumn{2}{|c|}{-91.696} & \multicolumn{2}{|c|}{-89.23} \\
\hline$\chi^{2}$ & \multicolumn{2}{|c|}{15.23} & \multicolumn{2}{|c|}{$33.23^{\star \star}$} & \multicolumn{2}{|c|}{$81.67^{\star *}$} & \\
\hline Pseudo $R^{2}$ & \multirow{2}{*}{\multicolumn{2}{|c|}{0.180}} & \multicolumn{2}{|c|}{0.392} & \multicolumn{2}{|c|}{0.308} & \multicolumn{2}{|c|}{0.327} \\
\hline$N$ & & & \multicolumn{2}{|c|}{196} & \multicolumn{2}{|c|}{196} & \multicolumn{2}{|c|}{196} \\
\hline
\end{tabular}

${ }^{\star *} p<.01 ;{ }^{\star} p<.05 ;$ two-tailed tests.

other variables we typically associate with incumbency advantages. ${ }^{11}$

A stronger test of the claim that incumbent quality has an electoral effect is to evaluate the direct impact of incumbent quality on vote share. Table 5 provides this test based on a Heckman model of incumbents' vote share in the 1998 election conditioned on the incumbent's decision to run. With this setup we recognize the potential importance of the

\footnotetext{
${ }^{11}$ One possibility is that the size of the personal quality effect stems from rationalization bias in survey responses since the measures of prospects and quality are drawn from the same survey instrument. However, there is no evidence of this based on a split-half analysis. We randomly divided district informants into two groups and drew the prospects measure from one group and the quality measure from the other. There was little difference in the magnitude of the coefficient in using the spilt-half versus the full sample $(.038 p<.01$ in one test and $.033 p<.05$ in the other).
}

incumbent's entry decision in shaping the campaign that follows, including the entry of quality challengers and the resources they attract. Moreover, variables that affect incumbents' decisions about running or retiring may also influence their vote share in the general election, and these factors may be excluded or imperfectly measured in our analysis.

The positive effect of incumbent quality on 1998 vote share supports the expectation that incumbents are rewarded when they are of high quality and punished when they are of lesser quality. Over the observed range of variation in incumbent quality in the sample, the difference in expected vote share won by the highest quality incumbent is $7.5 \%$ higher than the vote share won by the lowest quality incumbent.

The results in Table 5 show that the incumbent prospects variable has no independent effect on vote share, once its impact on incumbent entry, challenger 


\section{Figure 2 Probability of Incumbent and Serious Challenger Running}

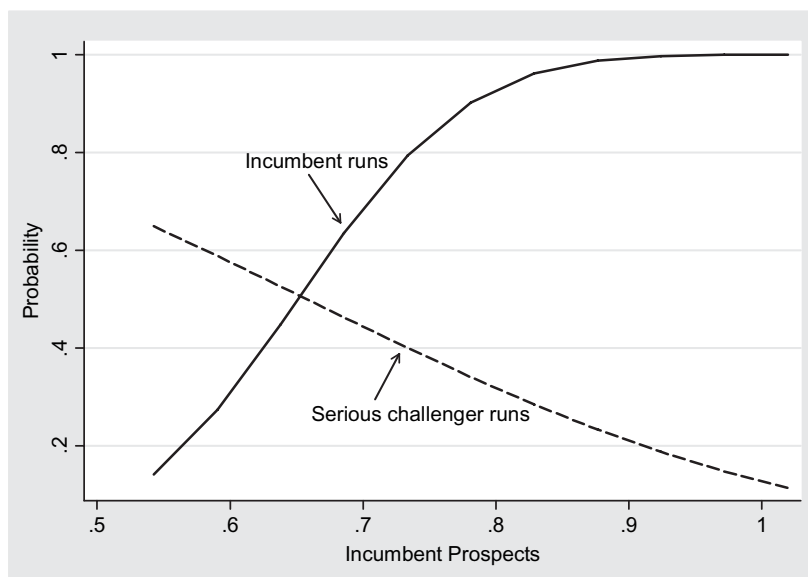

entry, and challenger expenditures is taken into account. This is appropriate since incumbents' prospects ought not have any direct causal impact on vote share aside from influencing candidate entry and other investments in the race.

That we find an impact of incumbent quality on vote share after controlling for prospects and incumbent and challenger entry is evidence that the electoral process responds to variation in incumbent quality. The average vote share among incumbents in our sample who were challenged was $64 \%$ with a standard deviation of $9.3 \%$, so it is plausible that the lowest quality incumbents would slip into the marginal category because of their relatively low quality. In a year when other factors worked against lowquality incumbents, their vulnerabilities could easily cumulate in electoral defeat.

As noted, a variety of mechanisms could account for how quality affects vote share. If lower quality incumbents have reduced prospects and therefore attract stronger challengers, such challengers should be in a better position to exploit vulnerabilities in the incumbent's character or record. This mechanism should be largely accounted for in our analysis, to the extent that lesser-quality incumbents have reduced prospects for victory, attract stronger challengers, or provide leverage for challengers to raise more money against them. ${ }^{12}$

Why, then, might our analysis reveal a direct effect of incumbent quality on vote share, especially

\footnotetext{
${ }^{12}$ Incumbents who attracted an experienced challenger in our sample were somewhat lower in quality than those who did not, although the effect is not statistically significant. Nonetheless, there is support for the deterrence effect of incumbent personal quality (Mondak 1995b).
}

TABLE 4 OLS Analysis of the Effect of Incumbent Quality on Electoral Prospects

\begin{tabular}{lcc}
\hline & $b$ & $S E$ \\
\hline Incumbent personal quality & $0.036^{* *}$ & 0.011 \\
District partisanship (favor incumbent) & $0.002^{\star}$ & 0.001 \\
Incumbent vote share, 1996 & $0.002^{* *}$ & 0.001 \\
Democratic incumbent & $-0.044^{\star *}$ & 0.013 \\
Serious challenger, 1996 & -0.008 & 0.014 \\
Challenger spending, 1996 (logged) & 0.008 & 0.006 \\
Incumbent spending, 1996 (logged) & $-0.021^{\star}$ & 0.009 \\
Incumbent cash on hand, 1996 (logged) & $0.014^{* *}$ & 0.005 \\
Incumbent number of terms served & -0.002 & 0.001 \\
Constant & $.682^{* *}$ & .139 \\
Adjusted $R^{2}$ & .271 \\
$F$ & $9.05^{* *}$ \\
$N$ & \multicolumn{2}{c}{196} \\
\hline${ }^{*} p<.01 ;{ }^{*} p<.05 ;$ two-tailed tests. & \multicolumn{2}{c}{} \\
\end{tabular}

when the model explicitly includes incumbent prospects? In other work we explore the possibility that voters themselves pick up on variation in incumbent quality, a finding that would further corroborate McCurley and Mondak's (1995) observation that voters' affect toward incumbents is influenced by quality. These and other mechanisms for a direct effect of incumbent quality on vote reflect the possibility that, although informants may take quality into account when they assess their Representative's prospects for reelection, they miss a significant part of the effect, perhaps because it is not entirely rooted in a strategic calculation by potential candidates and/or other key players in the process.

\section{Conclusion}

What are we to make of high reelection rates by incumbents to the U.S. House of Representatives? Because the behavior of incumbents and potential challengers is strategic, answering this fundamental question has been difficult, perhaps to a surprising degree. That incumbents are often reelected must be assessed in the context of their strategic calculations about whether to run at all. We have found that incumbent retirement is sensitive to their prospects for reelection. If incumbents are good at forecasting their own electoral fates when they opt out they forestall the electoral competition that would have occurred if they had run.

If incumbents were perfect prognosticators of their electoral fate, we might never observe them 
Table 5 Selection Model of Incumbent Vote Share Conditioned on the Decision to Run, 1998

\begin{tabular}{|c|c|c|}
\hline & $b$ & $S E$ \\
\hline \multicolumn{3}{|c|}{ Outcome model: Voteshare } \\
\hline $\begin{array}{l}\text { Incumbent vote } \\
\text { share, } 1996\end{array}$ & $0.237^{\star \star}$ & 0.074 \\
\hline District partisanship & $0.187^{*}$ & 0.088 \\
\hline $\begin{array}{l}\text { Democratic } \\
\text { incumbent, } 1998\end{array}$ & -0.414 & 1.528 \\
\hline $\begin{array}{l}\text { Serious challenger, } \\
1998\end{array}$ & 1.901 & 2.201 \\
\hline $\begin{array}{l}\text { Challenger } \\
\text { spending, } 1998 \\
\text { (logged) }\end{array}$ & $-4.836^{\star *}$ & 0.581 \\
\hline $\begin{array}{l}\text { Incumbent } \\
\text { prospects, } 1998\end{array}$ & -4.905 & 9.865 \\
\hline $\begin{array}{l}\text { Incumbent } \\
\text { personal quality }\end{array}$ & $2.763^{*}$ & 1.311 \\
\hline Constant & $98.499^{* *}$ & 11.778 \\
\hline \multicolumn{3}{|c|}{ Selection model: Decision to Run } \\
\hline $\begin{array}{l}\text { Incumbent vote } \\
\text { share, } 1996\end{array}$ & -0.059 & 0.039 \\
\hline District partisanship & -0.018 & 0.028 \\
\hline $\begin{array}{l}\text { Democratic } \\
\text { incumbent }\end{array}$ & 0.354 & 0.589 \\
\hline $\begin{array}{l}\text { Incumbent } \\
\text { spending, } 1996 \\
\text { (logged) }\end{array}$ & 0.399 & 0.231 \\
\hline $\begin{array}{l}\text { Serious challenger, } \\
1996\end{array}$ & 0.699 & 0.501 \\
\hline $\begin{array}{l}\text { Incumbent war } \\
\text { chest, } 1996 \\
\text { (logged) }\end{array}$ & -0.342 & 0.203 \\
\hline $\begin{array}{l}\text { Challenger } \\
\text { spending, } 1996 \\
\text { (logged) }\end{array}$ & $-0.746^{*}$ & 0.321 \\
\hline $\begin{array}{l}\text { Incumbent's } \\
\text { number of terms }\end{array}$ & $-0.142^{\star *}$ & 0.042 \\
\hline $\begin{array}{l}\text { Incumbent's } \\
\text { prospects }\end{array}$ & $10.233^{\star \star}$ & 2.696 \\
\hline Constant & 5.573 & 6.888 \\
\hline rho & -.604 & .250 \\
\hline LR Test $r h o=0$ & 2.87 & $\mathrm{p}>X^{2}=.090$ \\
\hline$N$ & 196 & \\
\hline Wald $X^{2}$ & & $340.34^{\star *}$ \\
\hline
\end{tabular}

${ }^{* *} p<.01 ;{ }^{*} p<.05$; two-tailed tests.

suffering electoral defeat. But incumbents sometimes are defeated, and they do more or less well in vote share, even when they are reelected. Part, though not all, of the explanation for how well they do is attributable to the quality and vigor of the challenge they draw. In addition, we find that electoral consequences follow as a consequence of incumbent quality. The quality effect works indirectly by affecting incumbent reelection prospects and directly by altering their vote share.

One might take our findings to indicate that electoral trouble or defeat of an incumbent reflects behavior by the incumbent that is out of equilibrium (cf. Buchler 2006). If an incumbent is defeated, he or she failed to anticipate the defeat and retire. A certain number of such miscalculations occur because politicians cannot perfectly forecast how national conditions will affect their reelection bid, or how strong the challenger might prove to be, or how local conditions will play out in the election. Surely one reason some incumbents venture into the arena even when defeat awaits them is that they fail to appreciate how their personal quality will be judged by voters. However, if the electoral process filters out politicians (including incumbents) of poor quality, the average incumbent will be of relatively high quality and most will win reelection.

Even in an apparently placid year like 1998 when the number of incumbent defeats appears to justify George Will's sarcastic view of incumbent safety, the push and pull of electoral politics beneath the surface reflects systematic variation in the quality of incumbents. While it may be too much to claim that incumbents win reelection because they do a good job, it does not seem extravagant to conclude that their quality stimulates electoral reward and sanction consistent with a relatively optimistic reading of how the electoral process works.

Strategic withdrawal by incumbents, strategic entry and resource deployment by challengers, and the impact of variation in the quality of incumbents means that a substantial amount of electoral competition is avoided not necessarily or only because incumbents manipulate the process to create an unfair advantage, but because they reap electoral rewards for doing their jobs well and have learned to anticipate the reactions of the electorate and avoid defeat when it is likely. Our reassessment of incumbency and electoral competition in elections places more weight on the positive consequences of candidate entry and incumbent quality, and less on the cynical manipulation of the electoral process by incumbents hellbent on reelection.

\section{Acknowledgments}

A previous version of this paper won the Pi Sigma Alpha award as the best paper presented at the 2004 annual meeting of the Western Political Science 
Association, Portland, OR. Thanks to Alan Abramowitz, Ben Bishin, James Fowler, Paul Gronke, Jonathan Katz, Dave Lewis, Ron Rapoport, John Zaller, participants in the University of California, Davis Micro Politics Group seminar, and the University of Pittsburgh seminar participants for helpful comments and suggestions. We are especially grateful to Ben Highton for his penetrating critique of an earlier draft. Gary Jacobson generously provided data; a grant from the National Science Foundation (SBR-9515350) supported the surveys and other data collections.

\section{Appendix}

\section{Assessing the Informant-Based Measures}

While we are the first to rely on district informants in a study of congressional elections, the use of informants in other fields and disciplines is common (Clinton and Lewis 2008; Marks et al. 2007; Ray 1999; Van Bruggen, Lilien, and Kacker 2002). As with other studies, widely accepted criterion variables are not available for some of the concepts we measure. Indeed, a primary reason for using informant-based measures is to capture characteristics of incumbents that cannot be otherwise measured. However, we can validate the general approach of using informant-based measures in U.S. House elections by comparing informant assessments of incumbent ideology and prospects to other well-accepted indicators such as roll-call votes and election vote shares.

The most direct comparison we can make is whether our informant-based measure rates the ideology of the incumbent similarly to ADA or NOMINATE scores, measures that are widely accepted as valid and reliable (see Bishin 2005; Poole and Rosenthal 1997; Smith, Herrera, and Herrera 1990). There is a strong correlation between our informant-based placements and incumbents' ADA scores $(\mathrm{r}=.92)$ and NOMINATE scores $(r=.94)$, which remains quite strong within party $(r=.75$ and .72 for Democrats and Republicans, respectively).

An analysis of errors (following Marks et al. 2007) in both the ideological placement and prospects variables (using NOMINATE and ADA scores as criterion variables for the informant placement variable and vote share as the criterion variable for prospects) shows that the error in the informantbased measures increases as the size of the informant sample decreases and as the within-district variance of informant ratings increases. These effects are weak $\left(R^{2} \leq .11\right)$ and there is no significant effect of other variables in the analysis, including incumbent seniority, party, and incumbent extremism.

Assessing the incumbent-quality measure is more difficult because no clear criterion variables are available. We have experimented with Fowler's (2006) measures of bill sponsorship, bill passage, and "connectedness," based on patterns of cosponsorship that describes the extent of the social network of each member in Congress. The number of bills passed and connectedness are significantly related to our informant-based measure of quality, but they are not related to vote share, nor does including them in our analysis of vote share affect the impact of the incumbentquality results reported in the paper. The general problem with measures linked to member behavior in the institution is that they often reflect a strategic response by incumbents, rather than capturing the underlying characteristics fundamental to the concept of incumbent quality.

We have also evaluated the between- and withindistrict reliabilities of the informant measures by making use of the accuracy of informant judgments about incumbent ideology when building the quality measures. Errors in individual informant judgments stem from two sources: random error and systematic bias. We know that there is partisan bias in individual informant ratings of incumbent quality, with informants rating incumbents in the same party substantially higher than they rate incumbents in the opposite party (Stone, Maisel, and Maestas 2004). As a result, the quality items (and, as a precaution, all other informant ratings) are corrected for partisan bias. ${ }^{13}$ To correct for random errors that occur when experts lack information on one or more dimension, we weight the importance of each informant in calculating district means by the degree to which they accurately place incumbents on the ideological spectrum (Clinton and Lewis 2008). ${ }^{14}$ Our assumption is that those unable to accurately identify incumbent ideology are less informed about other characteristics of the incumbent as well.

Our primary assessment of the validity and reliability of personal-quality measures is based on three distinct approaches. The first examines the

\footnotetext{
${ }^{13}$ We adjust individual informant ratings by regressing informant ratings on a party dummy $(+1$ to indicate the informant and incumbent are in the same party; -1 when they are in opposite parties), and adjusting each informant's rating to the intercept (0 implies an independent informant).

${ }^{14}$ The assumption is that informants closer in their rating to the NOMINATE score will also be more accurate, on average, in their ratings on other qualities. We calculate $d=\mid$ (z-ideology) (z-NOMINATE)|. The accuracy weight $W$ is the inverse of $d$ : $W=(1 / d)^{.5}$
} 
dimensionality of the 10 -item scale to determine whether the survey items included in the personal quality indicator are part of a single construct. Cronbach's alpha is .92 on the 10 items used to construct the quality measure. In addition, a factor analysis produces a single factor with an eigenvalue $>$ $1.0(5.63 ; 84 \%$ of the variance explained). The average loading on the first dimension was .77. Both the scale-reliability and factor-analytic results support the unidimensional structure to the data.

A second approach assesses the reliability of the incumbent quality measure as a single item based on one-way analysis of variance designed to evaluate the reliability of aggregated measures (Jones and Norrander 1996). The reliability coefficient approaches 1.0 or perfect reliability as the ratio of the cross-district variance to the variance assigned to the district and individual levels approaches unity. By this method, the reliability of the incumbent quality measure is .66, or "moderately reliable" by the Jones-Norrander (1995 302) standard.

A final measure developed by Brown and Hauenstein (2005) captures interrater agreement $\left(a_{w g}\right)$ based on the ratio of variation among raters within districts as a ratio of maximum possible variance within the district. The theoretical range of the measure is -1 to +1 , from maximum variance among raters to maximum agreement (Brown and Huaenstein 2005, 174). The personal quality measure has an interrater reliability $a_{w g}=.77$, which is a moderately strong level of reliability by the Brown and Hauenstein standard.

In sum, where available, criterion variables indicate strong evidence in support of informant-based measures. In the case of the personal-quality measure, reliabilities exceed accepted standards by several quite different models of reliability. The validity and reliability analysis recommends the use of district informants as a possible solution to a variety of measurement issues in the study of congressional elections, including questions that go beyond this particular paper. If district informants can provide reliable and valid information about incumbents, they probably can do likewise about challengers, which could enrich measures of challenger quality and of incumbent-challenger differentials.

\section{Manuscript submitted 6 March 2008 \\ Manuscript accepted for publication 21 May 2009}

\section{References}

Abramowitz, Alan I. 1991. "Incumbency, Campaign Spending, and the Decline of Incumbency in U.S. House Elections." Journal of Politics 53 (1): 34-56.
Anderson, James C. 1985. "A Measurement Model to Assess Measure-Specific Factors in Multiple-Informant Research." Journal of Marketing Research 22 (1): 86-92.

Benoit, Kenneth, and Michael Laver. 2007. "Estimating party policy positions: Comparing expert surveys and hand-coded content analysis" Electoral Studies 26 (1): 90-107.

Bishin, Benjamin G. 2005. "The Validity and Accuracy of Commonly Used Ideology Measures: A Consumer's Guide." American Review of Politics 25: 201-20.

Brace, Paul. 1985. "A Probabilistic Approach to Retirement from the U.S. Congress.” Legislative Studies Quarterly 10 (1): 107-23.

Brady, David W., Robert D'Onofrio, and Morris P. Fiorina. 2000. "The Nationalization of Electoral Forces Revisited." in David W. Brady, John F. Cogan, and Morris P. Fiorina eds., Continuity and Change in House Elections. Stanford, CA: Stanford University Press, 130-48.

Brown, Reagan D., and Neil M. A. Hauenstein. 2005. "Interrater Agreement Reconsidered: An Alternative to the rwg Indices." Organizational Research Methods 8 (2): 165-84.

Buchler, Justin. 2006. "A Deterrence Model of Candidate Positioning and Electoral Competition: An Alternative to the Spatial Voting Model." Paper presented at the annual meeting of the Midwest Political Science Association.

Carson, Jamie L., Erik J. Engstrom, and Jason M. Roberts. 2007. "Candidate Quality, the Personal Vote, and the Incumbency Advantage in Congress." American Political Science Review 101 (2): 289-302.

Castles, Francis G., and Peter Mair. 1984. "Left-Right Political Scales, Some "Experts" Judgments." European Journal of Political Research 12 (1): 73-88.

Clinton, Joshua D., and David E. Lewis. 2008. "Expert Opinion, Agency Characteristics, and Agency Preferences." Political Analysis 16 (1): 3-20.

Cover, Albert D., and Bruce S. Brumberg. 1982. "Baby Books and Ballots: the Impact of Congressional Mail on Constituent Opinion." American Political Science Review 76 (2): 347-59.

Cox, Gary W., and Jonathan N. Katz. 1996. "Why Did the Incumbency Advantage in U.S. House Elections Grow?" American Journal of Political Science 40 (2): 478-97.

Cox, Gary W., and Jonathan N. Katz. 2002. Elbridge Gerry's Salamander: The Electoral Consequences of the Reapportionment Revolution. Cambridge: Cambridge University Press.

Erikson, Robert S. 1971. "The Advantage of Incumbency in Congressional Elections.” Polity 3 (3): 395-405.

Erikson, Robert S., and Thomas R. Palfrey. 2000. "Equilibria in Campaign Spending Games: Theory and Data." American Political Science Review 94 (3): 595-605.

Fiorina, Morris P. 1977. Congress: Keystone of the Washington Establishment. New Haven, CT: Yale University Press.

Fowler, James H. 2006. "Legislative Cosponsorship Networks in the U.S. House and Senate." Social Networks 28 (4): 454-65.

Gelman, Andrew, and Gary King. 1990. "Estimating Incumbency Advantage without Bias.” American Journal of Political Science 34 (4): 1142-64.

Groseclose, Tim, and Keith Krehbiel. 1994. "Golden Parachutes, Rubber Checks, and Strategic Retirements from the 102nd House." American Journal of Political Science 39 (1): 75-99.

Hall, Richard L., and Robert P. Van Houweling. 1995. "Avarice and Ambition in Congress: Representatives' Decisions to Run or Retire from the U.S. House." American Political Science Review 89 (1): 121-36. 
Huber, John, and Ronald Inglehart. 1995. "Expert Interpretations of Party Space and Party Locations in 42 Societies." Party Politics 1 (1): 73-111.

Jacobson, Gary C. and Michael A. Dimock. 1994. "Checking Out: the Effects of Bank Overdrafts on the 1992 House Elections." American Journal of Political Science 38 (3): 601-24.

Jones, Bradford S. and Barbara Norrander. 1996. "The Reliability of Aggregated Public Opinion Measures." American Journal of Political Science 40 (1): 295-309.

Lazarus, Jeffrey. 2005. "Unintended Consequences: Anticipation of General election Outcomes and Primary Election Divisiveness." Legislative Studies Quarterly 30 (3): 435-61.

Lee, David S. 2008. "Randomized Experiments from Nonrandom Selection in U.S. House Elections." Journal of Econometrics 142 (2): 675-97.

Maestas, Cherie D., and Cynthia Rugeley. 2008. "Assessing the 'Experience Bonus' through Examining Strategic Entry, Candidate Quality, and Campaign Receipts in U.S. House Elections." American Journal of Political Science 52 (3): 520 35.

Marks, Gary, Liesbet Hooghe, Marco R. Steenbergen, and Ryan Bakker. 2007. "Crossvalidating Data on Party Positioning on European Integration.” Electoral Studies 26 (1): 23-38.

Mayhew, David. 1974. Congress: The Electoral Connection. New Haven, CT: Yale University Press.

McCurley, Carl, and Jeffery J. Mondak. 1995. "Inspected by \#1184063113: The Influence of Incumbents' Competence and Integrity in U.S. House Elections." American Journal of Political Science 39 (4): 864-85.

Mondak, Jeffery J. 1995a. "Elections as Filters: Term Limits and the Composition of the U.S. House." Political Research Quarterly 48 (4): 701-28.

Mondak, Jeffrey J. 1995b. "Competence, Integrity, and the Electoral Success of Congressional Incumbents." Journal of Politics 57 (4): 1043-69.

Moore, Michael K., and John R. Hibbing. 1998. "Situational Dissatisfaction in Congress: Explaining Voluntary Departures." Journal of Politics 60 (4): 1088-107.

Poole, Keith T. and Howard Rosenthal. 1997. Congress: A Political-Economic History of Roll Call Voting. New York: Oxford University Press.

Ray, Leonard. 1999. "Measuring Party Orientation towards European Integration: Results from and Expert Survey." European Journal of Political Research 36 (6): 283-306.
Seidler, John. 1974. "On Using Informants: A Technique for Collecting Quantitative Data and Controlling for Measurement Error in Organization Analysis." American Sociological Review 39 (4): 816-31.

Smith, Eric R. A. N, Richard Herrera, and Cheryl L. Herrera. 1990. "The Measurement Characteristics of Congressional Roll-Call Indexes.” Legislative Studies Quarterly 15 (2): 28395.

Stone, Walter J., L. Sandy Maisel, and Cherie D. Maestas. 2004. "Quality Counts: Extending the Strategic Politician Model of Incumbent Deterrence. American Journal of Political Science 48 (3): 479-95.

Surowiecki, James. 2004. The Wisdom of Crowds. New York: Doubleday.

Theriault, Sean M. 1998. "Moving Up or Moving Out: Career Ceilings and Congressional Retirement." Legislative Studies Quarterly 23 (3): 419-33.

Van Bruggen, Gerrit H., Gary L. Lilien, and Manish Kacker. 2002. "Informants in Organizational Marketing Research: Why Use Multiple Informants and How to Aggregate Responses." Journal of Marketing Research 39 (4): 469-78.

Wolak, Jennifer. 2007. "Strategic Retirements: The Influence of Public Preferences on Voluntary Departures from Congress." Legislative Studies Quarterly 32 (2): 285-308.

Zaller, John. 1998. "Politicians as Prize Fighters: Electoral Selection and Incumbency Advantage." In Politicians and Party Politics, ed. J. G. Geer. Baltimore: Johns Hopkins University Press, 125-85.

Walter J. Stone, is Professor of Political Science, University of California, Davis, Davis, CA 95616.

Sarah A. Fulton is Assistant Professor of Political Science, Texas A\&M University, College Station, TX 77843-4348.

Cherie D. Maestas is Associate Professor of Political Science, Florida State University, Tallahassee, FL 32306.

L. Sandy Maisel is Professor of Government, Colby College, Waterville, ME 04901-8840. 